\title{
Two annual maxima of nitrate reduction and denitrification in estuarine sediment (Norsminde Fjord, Denmark)
}

\author{
Kirsten Schannong Jørgensen, Jan Sørensen* \\ Department of Ecology and Genetics, University of Aarhus, Ny Munkegade, DK-8000 Aarhus C, Denmark
}

\begin{abstract}
In situ rates of $\mathrm{NO}_{3}^{-}$reduction and denitrification were measured in the sediment of a Danish estuary during 3 annual cycles. The acetylene inhibition technique was used with undisturbed sediment cores. A reproducible seasonal pattern was obtained for both total $\mathrm{NO}_{3}^{-}$reduction and denitrification rates. Both processes showed maximal activity in the spring and fall. High benthic primary production and subsequent degradation of the algal biomass seemed responsible for the spring maximum (May). In early spring, a diel denitrification pattern with low activity during the day was due to $\mathrm{O}_{2}$ production during benthic photosynthesis; the effect was most significant (up to $60 \%$ inhibition) when algal biomass was at a maximum (March-April). Low $\mathrm{NO}_{3}^{-}$concentrations during summer (June-September) were followed by higher $\mathrm{NO}_{3}^{-}$concentrations in the overlying water and seemed responsible for the second maximum in the fall (October-December). Temperature was the limiting factor for denitrification during winter (January-February). Over an annual cycle, $\mathrm{NO}_{3}$ reduction rates ranged from 10 to $40 \mathrm{mmol} \mathrm{N} \mathrm{m}^{-2} \mathrm{~d}^{-1}$ and denitrification rates from 2 to $10 \mathrm{mmol} \mathrm{N} \mathrm{m} \mathrm{m}^{-2} \mathrm{~d}^{-1}$ The annual activities of $\mathrm{NO}_{3}^{-}$reduction and denitrification were 6.7 and $1.8 \mathrm{~mol} \mathrm{~N} \mathrm{~m}^{-2} \mathrm{yr}^{-1}$, respectively, averaged over a 3 yr period.
\end{abstract}

\section{INTRODUCTION}

In coastal marine waters, $\mathrm{NO}_{3}^{-}$input from run-off and groundwater discharge (Capone \& Bautista 1985) may locally support high planktonic and benthic algae production. Elevated primary production may in turn cause higher decomposition rates in the bottom layers and frequently lead to significant $\mathrm{O}_{2}$ deficits in both the bottom waters and sediments. Among the decomposition processes, bacterial denitrification contributes to both the mineralization of organic matter and to sedimentary nitrogen cycling. The $\mathrm{NO}_{3}^{-}$transformation to gaseous $\mathrm{N}_{2}$ thus comprises a natural nutrient sink and may mitigate the increasing $\mathrm{NO}_{3}^{-}$discharge and primary productivity in coastal environments.

In spite of the apparent role of denitrification in marine eutrophication, only few long-term studies have dealt with the natural regulation of the process in coastal waters (Sørensen 1984, Jorgensen \& Sørensen 1985, Seitzinger \& Nixon 1985, Smith et al. 1985, Jen-

\footnotetext{
- Addressee for correspondence
}

sen et al. 1988 [companion article]). In estuaries, where the external $\mathrm{NO}_{3}^{-}$input sometimes exceeds the endogenous $\mathrm{NO}_{3}^{-}$production from nitrification in the sediment (Smith et al. 1985, King \& Nedwell 1987), the $\mathrm{NO}_{3}^{-}$level in the surface water may primarily determine the denitrification activity. Smith et al. (1985) reported a year-round relationship between denitrification and $\mathrm{NO}_{3}^{-}$availability in a subtropical estuary where summer rains gave a high allochthonous $\mathrm{NO}_{3}^{-}$ input from May to September. Locally, however, temperature, availability of $\mathrm{O}_{2}$ and $\mathrm{NO}_{3}^{-}$, accumulation of organic matter, etc., may all contribute to complicated denitrification patterns in the sediments (Andersen et al. 1984, Jensen et al. 1984, Sørensen 1984, Jørgensen \& Sørensen 1985, Jensen et al. 1988). In such cases, it is of prime importance to study the regional, seasonal and diel variations at short sampling intervals. The purpose of the present study, which involved a small $\mathrm{NO}_{3}^{-}$polluted estuary in Denmark, was to obtain a detailed pattern for the temporal variation of sediment denitrification during 3 annual cycles and to determine the role of a variety of controlling factors for the process. 


\section{MATERIALS AND METHODS}

Study site. The study site was a small estuary (Norsminde Fjord) on the east coast of Jutland, Denmark (Fig. 1). The sampling site, a subtidal mudflat near the river outlet, was described previously (Station 4) by Jorgensen \& Sørensen (1985). The water depth was about $0.5 \mathrm{~m}$; ice cover was typically from January to March. Due to the high discharge of riverine water in late winter, salinity varied from $0.5 \%$ (winter) to $12 \%$ (summer). Both temperature and salinity were determined regularly during the investigation. The sediment was a soft mud with a water content of about $60 \%$ and an organic content of about 5 to $15 \%$ (ignition loss); the latter reflected a seasonal variation. The surface zone of the sediment was oxidized and brown-colored (Fe hydroxides) to a depth of about $4 \mathrm{~cm}$ in winter, but only to about $0.5 \mathrm{~cm}$ depth in late summer. In the early spring, a dark-brown layer of benthic microalgae (mostly diatoms) could be observed on the sediment surface. The benthic fauna of polychaetes (Nereis sp.), tubificid worms and crustaceans (Corophium sp.) was scarce compared to the marine part of the estuary (Sørensen \& Glob 1987).

Sampling and core incubation. Water samples were taken in glass bottles and intact sediment cores in acrylic tubes at 2 to $4 \mathrm{wk}$ intervals during 3 annual cycles. The $15 \mathrm{~cm}$ long and $3.6 \mathrm{~cm}$ wide tubes were equipped with a vertical series of silicone-filled holes $(0.5 \mathrm{~cm}$ depth intervals $)$, which served as injection ports for the acetylene inhibitor used in the denitrification

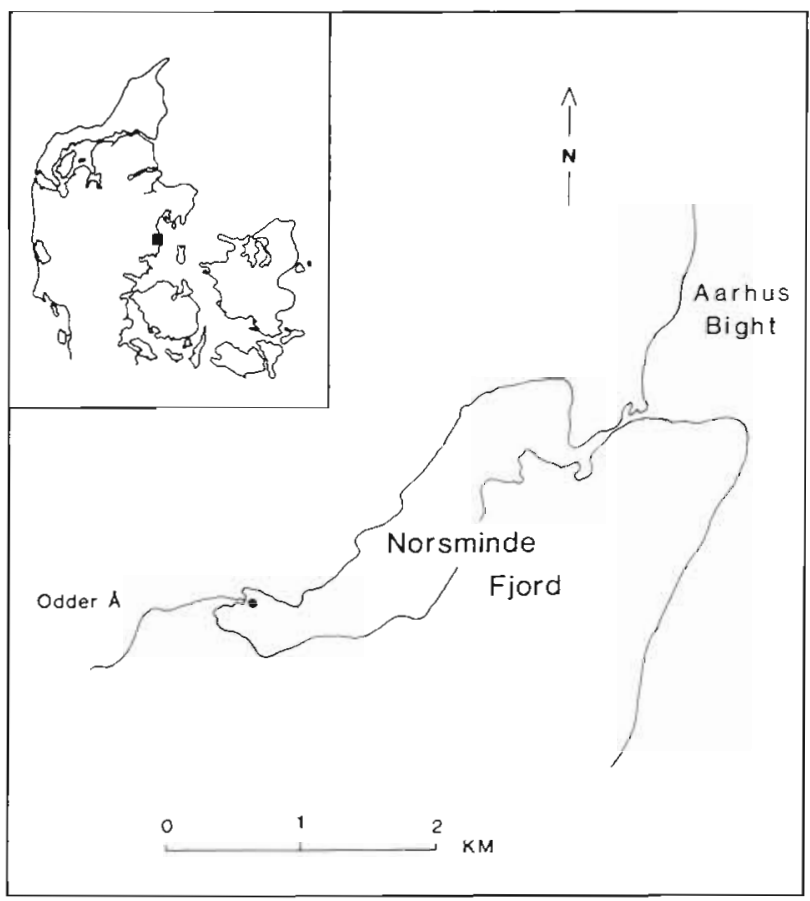

Fig. 1. Study site in Norsminde Fjord, Denmark assay (see below). All samples were brought to the laboratory within $3 \mathrm{~h}$. Water samples were frozen $\left(-20^{\circ} \mathrm{C}\right)$ for later analysis of $\mathrm{NO}_{3}^{-}$and cores were stored at in situ temperature under aerated and circulating water from the sampling site.

Water contents, densities and organic contents (ignition loss at $550^{\circ} \mathrm{C}$ ) were determined in 0.5 to $1 \mathrm{~cm}$ depth intervals of some of the cores. In other cores, the acetylene inhibition technique was used for the determination of both denitrification (Sørensen 1978b, Andersen et al. 1984) and total $\mathrm{NO}_{3}^{-}$reduction (Jørgensen \& Sorensen 1985); $\mathrm{C}_{2} \mathrm{H}_{2}$ blocks $\mathrm{N}_{2} \mathrm{O}$ reduction to $\mathrm{N}_{2}$ in denitrifying bacteria (Balderston et al. 1976, Yoshinari \& Knowles 1976) and analysis of $\mathrm{N}_{2} \mathrm{O}$ accumulation is therefore considered a measure of in situ denitrification activity. Furthermore, since $\mathrm{C}_{2} \mathrm{H}_{2}$ also inhibits $\mathrm{NH}_{4}^{+}$oxidation in the nitrifying bacteria (Walter et al. 1979, Hynes \& Knowles 1982), a determination of the consumption rate for $\mathrm{NO}_{3}^{-}$plus $\mathrm{NO}_{2}^{-}$should express the overall $\mathrm{NO}_{3}^{-}$-reducing activity in the cores (Jørgensen \& Sørensen 1985, Sørensen 1987).

In cores receiving $\mathrm{C}_{2} \mathrm{H}_{2}$, the sediment surface was first adjusted to a fixed position, about $6 \mathrm{~cm}$ from the upper edge of the tube. Water and gas phases corresponding to $30 \mathrm{ml}$ volumes $(3 \mathrm{~cm}$ height in the tubes) were included in the cores. $\mathrm{C}_{2} \mathrm{H}_{2}$-saturated, distilled water ( $200 \mu \mathrm{l}$ ) was then injected by syringe through each of the silicone-filled holes; the inhibitor was spread homogeneously in to the sediment. The water and gas phases also received $\mathrm{C}_{2} \mathrm{H}_{2}$ so that the final $\mathrm{C}_{2} \mathrm{H}_{2}$ concentration in both the sediment, water and gas phase was about $10 \%$ of saturation. After injection, the cores were immediately closed with gastight, light-permeable acrylic caps. A magnetic bar mounted inside the cap could be moved by a larger external magnet and served to stir the water phase. All cores were incubated at the in situ temperature in a thermostatted water bath and half of them were exposed to light through the caps. The light source was a $400 \mathrm{~W}$ mercury lamp (Osram HQI-T, Stuttgart, FRG) placed $60 \mathrm{~cm}$ above the sediment surface (light intensity $200 \mu \mathrm{E} \mathrm{cm}^{-2} \mathrm{~s}^{-1}$ ).

Extraction procedure and determination of activity. For both dark and light incubations, 4 cores were sacrificed for $\mathrm{NO}_{3}^{-}, \mathrm{NO}_{2}^{-}$and $\mathrm{N}_{2} \mathrm{O}$ analyses after $0,1,2$, and $3 \mathrm{~h}$, respectively. First, $3 \mathrm{ml}$ of the gas phase was injected into pre-evacuated 'Venoject' tubes (Terumo Europe N.V., Leuven, Belgium) for later analyses of $\mathrm{N}_{2} \mathrm{O}$. The core was then uncapped and $10 \mathrm{ml}$ of the water phase quickly transferred to a $60 \mathrm{ml}$ glass beaker. The uppermost $\mathrm{cm}$ of the sediment was cut into $0.5 \mathrm{~cm}$ segments followed by $1 \mathrm{~cm}$ segments down to $4 \mathrm{~cm}$ depth. Each segment was placed in a $60 \mathrm{ml}$ beaker containing $10 \mathrm{ml}$ of $2 \mathrm{~N} \mathrm{KCl}$ solution. After the transfer of a sample, the beaker was immediately capped with a rubber stopper and shaken vigorously by 
hand for $2 \mathrm{~min}$. A gas sample of $3 \mathrm{ml}$ was then withdrawn from the headspace and injected into a preevacuated glass vial for storage. Finally, both the water samples and the suspensions were centrifuged $(2000 \times$ g. $10 \mathrm{~min})$ and the supernatants frozen $\left(-20^{\circ} \mathrm{C}\right)$.

The $\mathrm{N}_{2} \mathrm{O}$ content in the gas samples were determined on a Packard model 427 gas chromatograph installed with a ${ }^{63} \mathrm{Ni}$ electron capture detector $\left(320^{\circ} \mathrm{C}\right)$. The gas chromatograph was equipped with a $2 \mathrm{~m}$ long Porapak $Q$ column to separate the sample components and a backflush system (Parkin et al. 1984) to avoid $\mathrm{C}_{2} \mathrm{H}_{2}$ contamination of the detector. Pure $\mathrm{N}_{2}$ served as the carrier gas ( $15 \mathrm{ml} \mathrm{min}^{-1}$ ) and oven temperature was $80^{\circ} \mathrm{C}$. This configuration allowed a gas sample to be injected every $3 \mathrm{~min}$.

The concentration of $\mathrm{N}_{2} \mathrm{O}$ in sediment and water samples was obtained from the measured $\mathrm{N}_{2} \mathrm{O}$ content in the gas sample and the Bunsen solubility coefficients for $\mathrm{N}_{2} \mathrm{O}$ in $\mathrm{KCl}$ solution or seawater (Markham \& Kobe 1941, Weiss \& Price 1980). Water content and density of the sediment were used to convert the measured concentrations into appropriate dimensions. The $\mathrm{N}_{2} \mathrm{O}$ accumulation was usually linear for the whole incubation period of $3 \mathrm{~h}$, but in a few cases with low $\mathrm{NO}_{3}^{-}$ concentrations, the production rate was only constant for 1 h (late summer); here, the rate of $\mathrm{N}_{2} \mathrm{O}$ accumulation decreased during the incubation, and the initial rate (first h) was used as an estimate of denitrification activity. The $\mathrm{N}_{2} \mathrm{O}$ recovered in the water and gas phases of the cores was anticipated to originate from activity in the upper $0.5 \mathrm{~cm}$ of the sediment (Andersen et al. 1984)

The $\mathrm{NO}_{3}^{-}$and $\mathrm{NO}_{2}^{-}$contents in the water phase and the supernatants were determined on a Chemlab autoanalyser using the method of Armstrong et al. (1967). Water contents and densities of the sediment were used to calculate the total $\mathrm{NO}_{3}^{-}$plus $\mathrm{NO}_{2}^{-}$content in each of the $\mathrm{C}_{2} \mathrm{H}_{2}$-treated cores. The rate of $\mathrm{NO}_{3}^{-}$consumption during the whole incubation period of $3 \mathrm{~h}$ was used to calculate the total $\mathrm{NO}_{3}^{-}$reduction in the sediment.

\section{RESULTS}

\section{$\mathrm{NO}_{3}^{-}$concentrations in the water and sediment}

Temperature and salinity varied predictably from February 1985 to February 1986 (Fig. 2). As indicated by low salinities, river discharge was generally highest
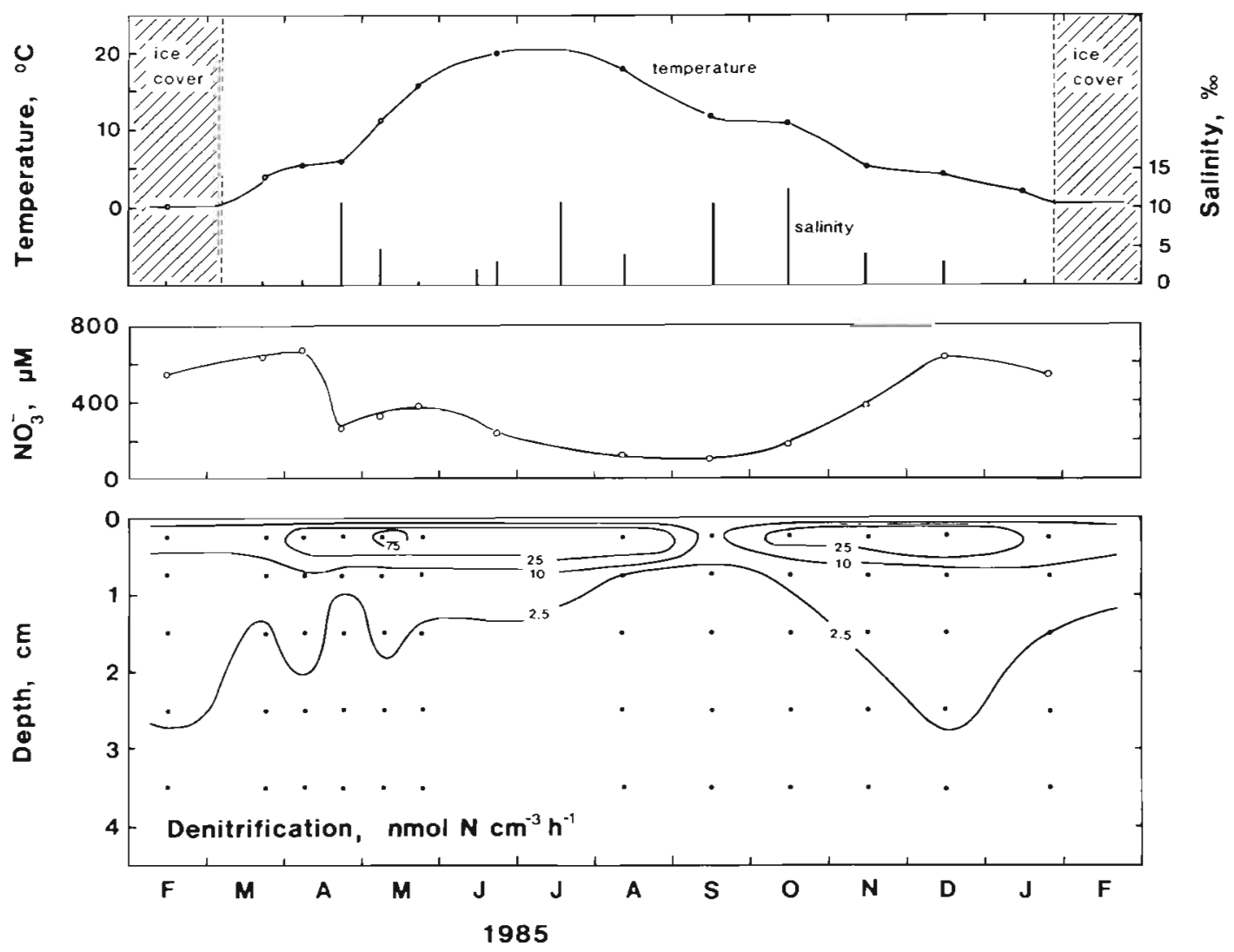

Fig. 2. Upper panel: Seasonal variation of salinity (columns) and temperature in Norsminde Fjord (February 1985 to February 1986 ). Middle panel: $\mathrm{NO}_{3}^{-}$concentrations in the water. Lower panel: Distribution of denitrification activity in the sediment (isopleths) 
in the winter and early spring. Nutrient input was also maximal at this time, when more than $500 \mu \mathrm{M} \mathrm{NO}-$ could be observed in surface waters. The lower $\mathrm{NO}_{3}^{-}$ concentrations of 100 to $250 \mu M$ during summer resulted from both lower water discharge and the rapid nutrient consumption in the spring (Jørgensen \& Sørensen 1985). Throughout the year, $\mathrm{NO}_{3}^{-}$concentrations in the sediment seemed largely controlled by the load of $\mathrm{NO}_{3}^{-}$in the overlying water phase of the estuary. In the upper $0.5 \mathrm{~cm}$ depth interval, which contained the highest $\mathrm{NO}_{3}^{-}$concentration in the sediment, about $300 \mu M$ was observed in winter (January 1986) and $10 \mu \mathrm{M}$ in summer (September 1985) (data not shown). Thus, as judged from the concentration gradient at the sediment-water interface, there was always a transport of $\mathrm{NO}_{3}^{-}$from the water into the sediment.

\section{Denitrification in the sediment}

The depth of the denitrification zone is indicated in Fig. 2 (lower panel). Little activity was found below the uppermost $\mathrm{cm}$ and between 50 and $90 \%$ of the measured denitrification was located within the uppermost $0.5 \mathrm{~cm}$ segment. The profiles also reveal 2 annual maxima of denitrification activity in the surface layer, one in the spring (May) and one in the fall (October to
December). A minimum of activity thus appeared in late summer (September) when the temperature was relatively high, but the $\mathrm{NO}_{3}^{-}$concentrations had decreased to $100 \mu \mathrm{M}$ in the overlying water and about $10 \mu M$ in the surface layer of the sediment. Finally, when the temperature decreased in the winter, the second minimum of denitrification activity appeared, even though $\mathrm{NO}_{3}^{-}$concentrations were again relatively high.

In spite of the variation expected from heterogeneity in the sediment, the spring and fall denitrification maxima could be discerned for all 3 yr of the investigation. (Fig. 3). The range of activities was also similar from year to year; peak values in the spring and fall were about $10 \mathrm{mmol} \mathrm{N} \mathrm{m}^{-2} \mathrm{~d}^{-1}$ and minimum values in the summer and winter about $2 \mathrm{mmol} \mathrm{N} \mathrm{m}^{-2} \mathrm{~d}^{-1}$.

The inhibition of denitrification by light was most pronounced in early spring (March-April) when the activity was $60 \%$ lower in the light-incubated cores than in the dark-incubated ones (Fig. 4, upper panel). Strongest inhibition was thus observed 1 to 2 mo before the appearance of the denitrification maximum in May and was best correlated with development of a benthic algal mat. The increase of organic content at the surface, from about $5 \%$ in winter to about $15 \%$ in early spring, illustrated the elevated production and biomass of the benthic micro-algae (Fig. 4, lower panel).

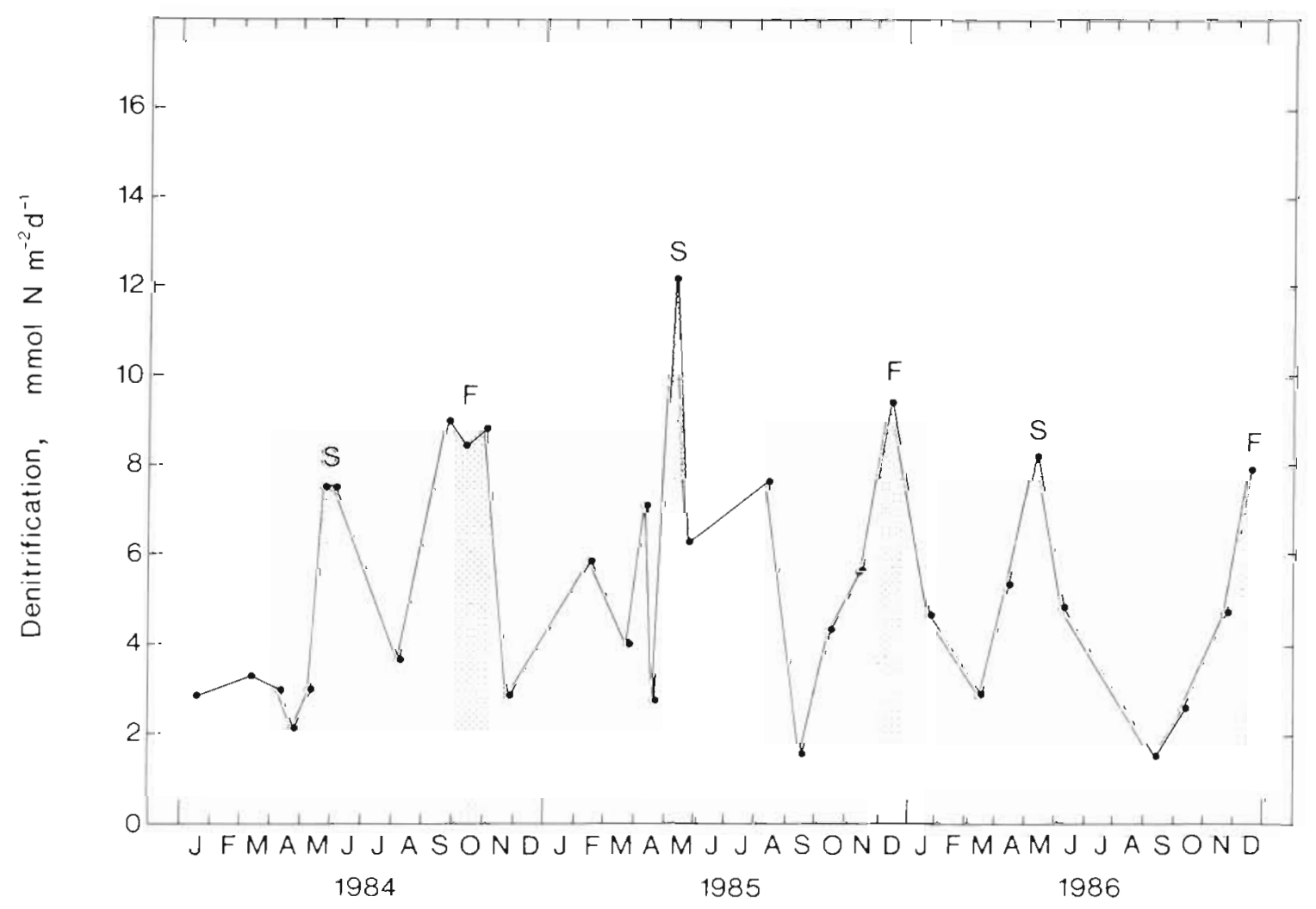

Fig. 3. Seasonal variation of the denitrification activity in the Norsminde Fjord Sediment (1984 to 1986). Shaded areas indicate periods of high denitrification activity in spring (S) and fall (F) 


\section{$\mathrm{NO}_{3}^{-}$reduction in the sediment}

The annual patterns for total $\mathrm{NO}_{3}^{-}$-reducing activity also show a marked seasonal variation with 2 consistent maxima, one in the spring (May) and one in the fall (October to December) (Fig. 5). Peak values of $\mathrm{NO}_{3}^{-}$ reduction (spring and fall) were about $40 \mathrm{mmol} \mathrm{N} \mathrm{m}^{-2}$ $\mathrm{d}^{-1}$ and minimum values (summer and winter) about 10 mmol $\mathrm{N} \mathrm{m}^{-2} \mathrm{~d}^{-1}$.

Except for 2 occasions in late summer and early fall (September 1985 and October 1986), the concurrent measurements of denitrification and total $\mathrm{NO}_{3}^{-}$reduction showed that total $\mathrm{NO}_{3}^{-}$reduction was from 1.5 to 7 times higher than denitrification (Fig. 6). For the 2 exceptions, denitrification accounted for less than $10 \%$ of the total $\mathrm{NO}_{3}^{-}$reduction; in these instances the sediment was highly reduced and contained only about $10 \mu \mathrm{M} \mathrm{NO}_{3}^{-}$in the uppermost $0.5 \mathrm{~cm}$ segment. Otherwise, there was no apparent correlation between the sampling time $\left(\mathrm{NO}_{3}^{-}\right.$level) and the ratio of denitrification to total $\mathrm{NO}_{3}^{-}$reduction.

\section{DISCUSSION}

\section{Seasonal and diurnal variation of denitrification}

A consistent seasonal pattern of in situ denitrification was found in the Norsminde Fjord estuary; during $3 \mathrm{yr}$ of investigation, from 1984 to 1986, maxima were found in mid-spring (May) and in fall (October to December). The spring maximum was previously observed in an earlier study (Sørensen 1984, Jørgensen \& Sørensen 1985), but this is the first report of the fall maximum.

The increasing temperature in early spring should generally stimulate the activity in the sediment, but temperature and denitrification from February to May, 1984 to 1986, were not correlated by an Arrhenius equation (data not shown). Other factors such as increased availability of organic substrate due to decomposition of benthic algae seemed to be more important. For example, the spring denitrification maximum was correlated with a rapid decline of sediment organic content in May (Fig. 4). The decline in organic content was probably a result of intensive grazing and decomposition of the surface microalgal mat. During this period, a general increase of heterotrophic activity has previously been observed from the rates of $\mathrm{O}_{2}$ uptake in the sediment (Jørgensen \& Sørensen 1985). It is important to note that $\mathrm{NO}_{3}^{-}$concentrations in the estuarine water were still relatively high in May. The subsequent decrease of denitrification in the summer could thus be a response to limited $\mathrm{NO}_{3}^{-}$availability (lower concentrations and smaller penetration depth in the sediment). As judged from the high rates of $\mathrm{O}_{2}$ uptake (Jørgensen \& Sørensen 1985) it seems unlikely that availability of organic substrate would be a limiting factor during summer. The regulation of denitrification by $\mathrm{NO}_{3}^{-}$availability in the summer was further supported by the appearance of a denitrification maximum in the fall when $\mathrm{NO}_{3}^{-}$concentrations increased. The minimum in the winter was most likely controlled by low temperature.
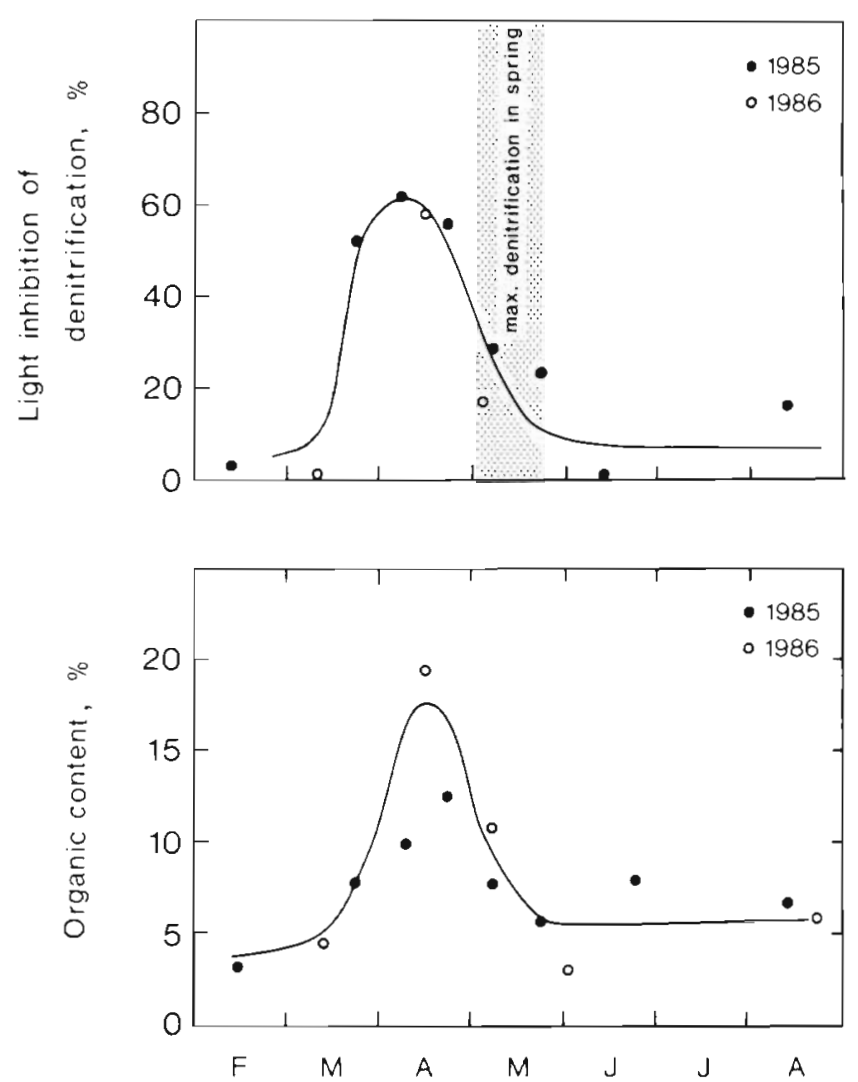

Fig. 4. Upper panel: Seasonal variation of light inhibition of denitrification activity. Shaded area indicates period of maximum denitrification in spring. Lower panel: Seasonal variation of organic content (ignition loss) in the uppermost $\mathrm{cm}$ of the Norsminde Fjord sediment

The effect of light-and-dark cycles on denitrification activity was pronounced in early spring (March-April), when a dense population of microalgae appeared on the sediment surface. Benthic photosynthesis may increase the $\mathrm{O}_{2}$ penetration into the sediment (Sørensen et al. 1979, Revsbech et al. 1981, Jensen et al. 1984, Baillie 1986) and thus result in significant inhibition of the surface-located denitrification. Andersen et al. (1984) demonstrated such a diel denitrification pattern, with low activities in the daytime, during a period of intensive benthic primary production in April. The present study demonstrates light inhibition of denitrification during the whole spring period of elevated benthic productivity. 


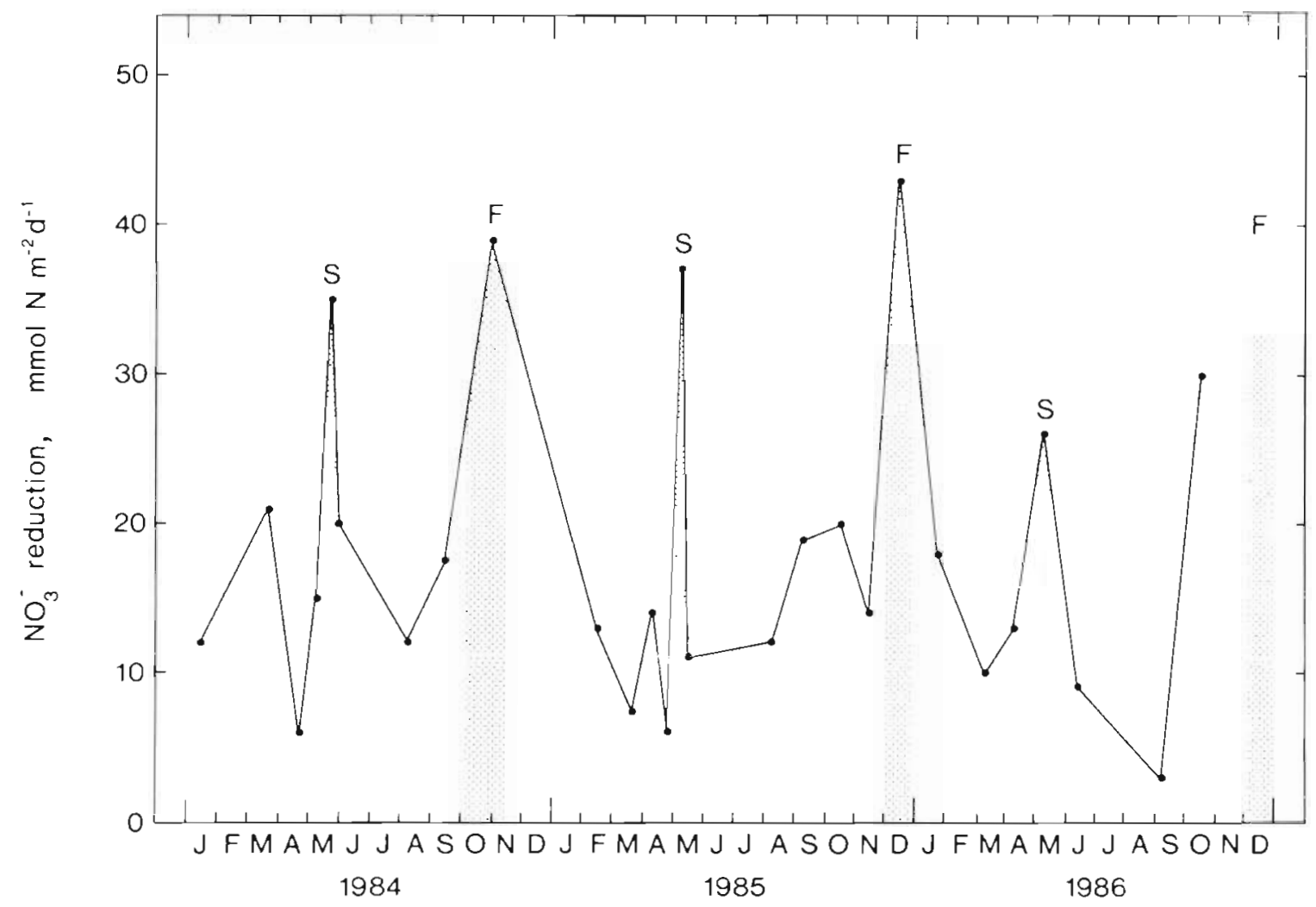

Fig. 5. Seasonal variation of total $\mathrm{NO}_{3}^{-}$-reducing activity in the Norsminde Fjord sediment (1984 to 1986). For a comparison of the seasonal patterns of denitrification and total $\mathrm{NO}_{3}^{-}$reduction, periods of high denitrification activity in spring (S) and fall (F) are indicated (shaded areas)

\section{Significance of denitrification and other $\mathrm{NO}_{3}^{-}$-reducing activity}

The seasonal cycle of total $\mathrm{NO}_{3}^{-}$reduction showed the same maxima in the spring and fall as found for denitrification. This indicated that the 2 processes were controlled by similar environmental factors. For single measurements, denitrification accounted for a most variable fraction, from 15 to $70 \%$, of the total $\mathrm{NO}_{3}^{-}$ reduction; for a whole year, however, the fraction was surprisingly constant, about $30 \%$ for 1984, 1985 and 1986 (see below). Nishio et al. (1982) also observed in an estuarine sediment that denitrification accounted for about 30 to $60 \%$ of the overall $\mathrm{NO}_{3}^{-}$reduction. Jørgensen \& Sørensen (1985) attributed the difference between $\mathrm{NO}_{3}^{-}$reduction and denitrification to bacterial ' $\mathrm{NO}_{3}^{-}$ammonification' (dissimilatory $\mathrm{NO}_{3}^{-}$reduction to $\mathrm{NH}_{4}^{+}$). ' $\mathrm{NO}_{3}^{-}$ammonification' can be readily demonstrated in ${ }^{15} \mathrm{NO}_{3}^{-}$-amended sediments (Koike \& Hattori 1978, Sørensen 1978a, Enoksson \& Samuelsson 1987, K. S. Jørgensen unpubl.), but it has been most difficult to determine its in situ significance even at low $\mathrm{NO}_{3}^{-}$ concentrations. From current evidence, however, it seems that a $\mathrm{NO}_{3}^{-}$-reducing activity other than denitrification (probably ' $\mathrm{NO}_{3}^{-}$ammonification') may some- times comprise a major fraction of the overall $\mathrm{NO}_{3}^{-}$ reduction in estuarine sediments. Alternatively, it has also been argued that incomplete blockage by $\mathrm{C}_{2} \mathrm{H}_{2}$ may sometimes lead to an underestimate of denitrification. Incomplete $\mathrm{C}_{2} \mathrm{H}_{2}$ blockage has been reported in relatively reduced sediments with low $\mathrm{NO}_{3}^{-}$concentrations (Kaspar 1982, Oremland et al. 1984), but only twice (in $3 \mathrm{yr}$ ) was the $\mathrm{NO}_{3}^{-}$concentration as low as 10 $\mu M$ in the uppermost depth interval (both occurring in late summer). At these times the sediment was indeed relatively reduced after a period of complete anoxia in the bottom water. The 2 occasions were the only ones with extraordinarily low rates of denitrification relative to $\mathrm{NO}_{3}^{-}$reduction; denitrification may have been underestimated in these cases. One possible explanation for this problem could be the alleviation of the $\mathrm{C}_{2} \mathrm{H}_{2}$ blockage by sulfide (Tam \& Knowles 1979, Sørensen et al. 1987)

The annual rates of $\mathrm{NO}_{3}^{-}$reduction, measured in dark-incubated cores, were $7.0,6.0$ and $6.1 \mathrm{~mol} \mathrm{~N} \mathrm{~m}^{-2}$ $\mathrm{yr}^{-1}$ (Table 1). Denitrification rates were 1.8, 2.0 and $1.4 \mathrm{~mol} \mathrm{~N} \mathrm{~m}^{-2} \mathrm{yr}^{-1}$ for 1984, 1985 and 1986, respectively, after correction for light inhibition during spring Denitrification thus accounted for about $30 \%$ of total $\mathrm{NO}_{3}^{-}$reduction in all $3 \mathrm{yr}$ The areal $\mathrm{NO}_{3}^{-}$load of the 

reduction in the Norsminde Fjord sediment (1984 to 1986). Two data points (September 1985 and October 1986) had very low $\mathrm{NO}_{3}^{-}$concentrations (about 10 $u M$ ) in the uppermost $\mathrm{cm}$ of the sediment
Fig. 6. Denitrification versus total $\mathrm{NO}_{3}^{-}$

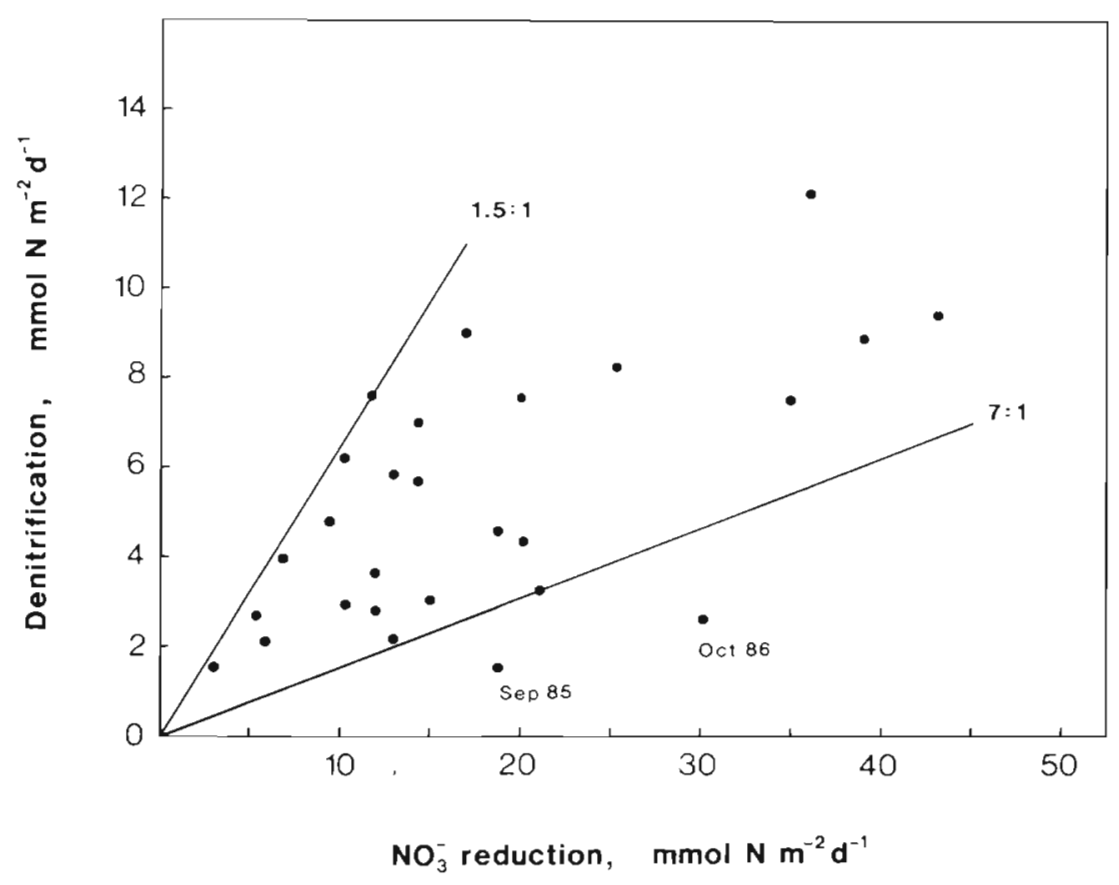

LITERATURE CITED

estuary (Table 1) was calculated from the riverine nutrient discharge and the total area of the estuary $\left(1.9 \mathrm{~km}^{2}\right)$. The percentage of the external $\mathrm{NO}_{3}^{-}$input which could potentially be removed by denitrification was $25 \%$, assuming that the measured denitrification was representative for the whole estuary. Actually, the activity decreases towards the marine part of the estuary (Jørgensen \& Sørensen 1985) and the denitrified fraction of the input must be lower. Nitrate not lost during denitrification is either trapped by sedimentation in the estuary or exported to the sea as plankton or suspended detritus (Jørgensen \& Sørensen 1985).

Table 1. Annual $\mathrm{NO}_{3}^{-}$load and activities of $\mathrm{NO}_{3}^{-}$reduction and denitrification (all mol N m${ }^{-2} \mathrm{yr}^{-1}$ ) in Norsminde Fjord estuary

\begin{tabular}{|c|c|c|c|}
\hline Year & $\mathrm{NO}_{3}^{-} \operatorname{load}^{\mathrm{a}}$ & $\begin{array}{l}\mathrm{NO}_{3}^{-} \text {reduction } \\
\left(\mathrm{mol} \mathrm{N} \mathrm{m}^{-2} \mathrm{yr}^{-1}\right)\end{array}$ & Denitrification $^{b}$ \\
\hline 1984 & 10.0 & 7.1 (ND) & $1.8(1.8)$ \\
\hline 1985 & 9.9 & $6.2(5.8)$ & $2.1(2.0)$ \\
\hline 1986 & 5.7 & 6.1 (ND) & $1.6(1.4)$ \\
\hline \multicolumn{4}{|c|}{$\begin{array}{l}\text { "Calculated from riverine discharge of } \mathrm{NO}_{3}^{-} \text {and area of } \\
\text { estuary } \\
{ }^{2} \text { Numbers in parentheses indicate activity corrected for } \\
\text { inhibition by light in the daytime } \\
\mathrm{ND} \text { : not determined }\end{array}$} \\
\hline
\end{tabular}

Acknowledgements. We thank Mikael Hjorth Jensen for valuable discussions, Birte Eriksen for technical assistance, and Anni Jensen for typing the manuscript. We also thank Det Danske Hedeselskab and Aarhus Amts Vandvæsen for permission to use their river discharge data.
Andersen, T K., Jensen, M. H., Sørensen, J. (1984). Diurnal variation of nitrogen cycling in coastal, marine sediments. I. Denitrification. Mar Biol 83: 171-176

Armstrong, F. A. J., Stearns, C. R., Strickland, J. D. H. (1967). The measurement of upwelling and subsequent biological processes by means of the Technicon Autoanalyser and associated equipment. Deep Sea Res. 14: 381-389

Baillie, P. W. (1986). Oxygenation of intertidal estuarine sediment by benthic microalgal photosynthesis. Estuar. coast Shelf Sci. 22: 143-159

Balderston, W. L., Sherr, B., Payne, W. J. (1976). Blockage by acetylene of nitrous oxide reduction in $P_{\text {seudomonas per- }}$ fectomarinus. Appl. environ. Microbiol. 31: 504-508

Capone, D. G. Bautista, M. F. (1985). A groundwater source of nitrate in nearshore sediments. Nature, Lond. 313: $214-216$

Enoksson, V., Samuelsson, M.-O. (1987). Nitrification and dissimilatory ammonium production and their effects on nitrogen flux over the sediment-water interface in bioturbated coastal sediments. Mar. Ecol. Prog. Ser. 36: 181-189

Hynes, R. K., Knowles, R. (1982). Effect of acetylene on autotrophic and heterotrophic nitrification. Can. J. Microbiol. 28: $334-340$

Jensen, H. B., Jorgensen, K. S., Sørensen, J. (1984). Diurnal variation of nitrogen cycling in coastal, marine sediments. II. Nitrous oxide emission. Mar. Biol. 83: 177--183

Jensen, M. H., Andersen, T K., Sorensen, J. (1988). Denitrification in coastal bay sediment: regional and seasonal variation in Aarhus Bight, Denmark. Mar. Ecol. Prog. Ser. 48: 155-162

Jørgensen, B. B., Sørensen, J. (1985). Seasonal cycles of $\mathrm{O}_{2}$, $\mathrm{NO}_{3}^{-}$and $\mathrm{SO}_{4}^{2-}$ reduction in estuarine sediments: the significance of an $\mathrm{NO}_{3}^{-}$reduction maximum in spring. Mar. Ecol. Prog. Ser. 24: 65-74

Kaspar, H. F. (1982). Denitrification in marine sediment: Measurement of capacity and estimate of in situ rate. Appl. environ. Microbiol. 43: 522-527 
King, D., Nedwell, D. B. (1987). The adaptation of nitratereducing bacterial communities in estuarine sediments in response to overlying nitrate load. FEMS Microbiol. Ecol. 45: $15-20$

Koike, I., Hattori, A. (1978). Denitrification and ammonia formation in anaerobic coastal sediments. Appl. environ. Microbiol. 35: 278-282

Markham, A. E., Kobe, K. A. (1941). The solubility of carbon dioxide and nitrous oxide in aqueous salt solutions. J. Am. Chem. Soc. 63: 449-454

Nishio, T., Koike, I., Hattori, A. (1982). Denitrification, nitrate reduction, and oxygen consumption in coastal and estuarine sediments. Appl environ. Microbiol. 43: 648-653

Oremland, R. S., Umberger, C., Culbertson, C. W., Smith, R. L. (1984). Denitrification in San Francisco Bay intertidal sediments. Appl. environ. Microbiol. 47: 1106-1112

Parkin, T B., Kaspar, H. F., Sexstone, A. J., Tiedje, J. M. (1984). A gas-flow soil core method to measure field denitrification rates. Soil Biol. Biochem. 16: 323-330

Revsbech, N. P., Jørgensen, B. B., Brix, O. (1981). Primary production of microalgae in sediments measured by oxygen microprofile, $\mathrm{H}^{14} \mathrm{CO}_{3}^{-}$fixation, and oxygen exchange methods. Limnol. Oceanogr. 26: 717-730

Seitzinger, S. P., Nixon, S. W. (1985). Eutrophication and the rate of denitrification and $\mathrm{N}_{2} \mathrm{O}$ production in coastal marine sediments. Limnol. Oceanogr. 30: 1332-1339

Smith, C. J., DeLaune, R. D., Patrick, Jr., W. H. (1985). Fate of riverine nitrate entering an estuary: I. Denitrification and nitrogen burial. Estuaries 8: 15-21

Sørensen, J. (1978a). Capacity for denitrification and reduction of nitrate to ammonium in a coastal marine sediment. Appl. environ. Microbiol. 35: 301-305
Sorensen, J. (1978b). Denitrification rates in a marine sediment as measured by the acetylene inhibition technique. Appl. environ. Microbiol. 35: 139-143

Sørensen, J. (1984). Seasonal variation and control of oxygen, nitrate, and sulfate respiration in coastal marine sediments. In: Klug, M. J., Reddy, C. A. (eds.) Current perspectives in microbial ecology. Am. Soc. Microbiol., Washington D. C., p. $447-453$

Sørensen, J. (1987). Nitrate reduction in marine sediment: pathways and interactions with iron and sulfur cycling. Geomicrobiol. J. 56: 401-421

Serensen, J., Glob, E. (1987). Influence of benthic fauna on trimethylamine concentrations in coastal marine sediments. Mar. Ecol. Prog. Ser 39: 15-21

Sørensen, J., Jørgensen, B. B., Revsbech, N. P. (1979). A comparison of oxygen, nitrate and sulfate respiration in coastal marine sediments. Microb. Ecol. 5: 105-115

Sørensen, J., Rasmussen, L. K., Koike, I. (1987). Micromolar sulfide concentrations alleviate acetylene blockage of nitrous oxide reduction by denitrifying Pseudomonas fluorescens. Can J. Microbiol. 33: 1001-1005

Tam, T.-Y., Knowles, R. (1979). Effects of sulfide and acetylene on nitrous oxide reduction by denitrifying bacteria. Can. J. Microbiol. 25: 1133-1138

Walter, H. M., Keeney, D. R., Fillary, I. R. (1979). Inhibition of nitrification by acetylene. Soil Sci. Soc. Am. J. 43: 195-196

Yoshinari, T., Knowles, R. (1976). Acetylene inhibition of nitrous oxide reduction by denitrifying bacteria. Biochem. Biophys. Res. Commun. 69: 705-710

Weiss, R. F., Price, B. A. (1980). Nitrous oxide solubility in water and seawater. Mar. Chem. 8: 347-359

This article was presented by Professor T. Fenchel; it was accepted for printing on June 23, 1988 